Mia Lövheim, Linnea Jensdotter

\title{
Chapter 8 \\ Contradicting Ideals: Islam on Swedish Public Service Radio
}

\begin{abstract}
Cultural and religious diversity are contested topics in Swedish public debate. This chapter analyses how the radio programme Människor och tro (People and belief) enables and structures the actors and issues that become heard in this debate, particularly with regard to Islam and Muslims. The programme aims to present an alternative to the dominant negative media discourses by equally representing Christianity and Islam in reports, inviting Swedish Muslims to present experiences and opinions on various news events, and enabling debate between religious organizations, experts, and listeners through phone-in sessions and social media. Despite these efforts, the programme tends to reconstruct, as well as challenge, the dominant frames of Islam as a problem for Swedish society and for the relations of power between the majority and minority voices in public debates. The chapter explores how contradictions between the traditional ideals and formats of public service radio and its ambitions to produce a more nuanced and diverse image of religion contribute to this outcome.
\end{abstract}

Keywords: public service radio, Sweden, Islam, phone-in session, women

Public service media (PSM) faces challenges both regarding changes within the media landscape and due to the enhanced religious and cultural diversification of the "public" that it is commissioned to service. As described in Chapter 5, Swedish public service broadcasters seem, in comparison with Norway and Denmark, more obliged to consider this dimension in the balancing act between serving a common national culture and enhancing cultural pluralism. Människor och tro (People and belief), the programme which is the focus of this chapter, has been broadcast weekly in its current format on Swedish public service radio since the 1990s. This long history makes it unique in a Swedish, as well as in a Nordic context, as a current affairs programme that is focused on religion. The P1 channel features high-quality news about politics, science, and art and it reaches an audience of about 14 percent of the population (Kantar Sifo 2017). As part of this genre, Människor och tro is a programme that primarily serves an educated, middle-aged segment of the public, and its audience numbers a few percent of the Swedish public. This, however, makes the programme 
an interesting example of how public service media seek to manage the crosspressures between, on the one hand, obligations to service the traditional segment of high-brow listeners and, on the other, the need to attract a new and younger audience with a more diverse cultural background and expectations of popular coverage of religious topics. As shown in a recent survey (see Chapter 2), Swedes stand out among the Scandinavians as being more tolerant towards public expressions of religious diversity, in particular of Islam. In recent years, migration to Sweden has increased, particularly since 2015 as a result of the escalating war in Syria. Combined with growing support for right-wing nationalist political opinions, cultural and religious diversity have become highly contested topics in Swedish public debate.

Through its mandate to serve all citizens, public service radio plays an important role in enabling and structuring the visibility of issues and of various perspectives concerning religion in the public sphere. This also means that public service programmes on religion can become arenas for enacting controversies about the legitimate place of religious values and actors in society. In this chapter, we ask how the programme Människor och tro represents religious diversity in Sweden, with a particular focus on the visibility of actors, perspectives, and issues related to Islam.

\subsection{Public Service Media and Religion in Sweden}

As in the other Scandinavian countries, public service media have a strong position in Sweden. Despite challenges from other media providers, 58 percent of the population still listen to public service radio (SR) daily (Nordicom 2016). More than 60 percent trust public service media and have a positive view of the broadcasters (Ipsos 2016). The change from minority programming to a mainstreaming of cultural diversity policy, which is described in Chapter 5 (see also Horsti and Hultén 2011) is reflected in a renewed policy, brought into being in 2015, in Swedish public service television and radio. Religion, faith, and other life views are to be included among the perspectives from which Swedish PSM are to carry out its coverage of Swedish society.

Studies of the coverage of Islam in Swedish news media (Axner 2015; Brune 2006) show that Islam, Muslim believers and Muslims as a social category are predominantly represented in connection with international conflicts, terrorism, and extremism. News about Islam in Sweden tends to focus on tensions between Islam and the rights of women, and discrimination against Muslims. Although exceptions exist, the everyday life of Muslim believers and the variety among various traditions and ways of practicing Islam is less often portrayed. Brune 
(2006, 91) argues that Swedish news media therefore produces a powerful and repeated othering, primarily of Muslims, who are turned into the carriers of characteristics that are seen as being unwanted in Swedish culture. These dominant trends are reported in studies that focus on news media and that use quantitative methodologies based on search words such as 'Islam'. In order to get a fuller understanding of the representation of Islam and Muslims in Swedish media it is, therefore, important to study different kinds of media and to analyse representation in particular media formats in-depth.

The general guidelines of Swedish public service radio emphasize plurality and an ambition to counter prejudices and stereotypes, as well as to look for 'new and unexpected voices'. ${ }^{1}$ The specific policy formulations for representing ethnicity and religion, or life views (livsåskådningar), state: 'We allow in all contexts participants from different ethnic and cultural backgrounds to be presented as individuals and not primarily as representatives of a particular group.' The policy goes on to say that religious affiliation should not be stated unless 'relevant for context', and words such as 'fundamentalist', 'militant', or 'Islamist' should be used with great care.

\subsection{Människor och tro: Current Affairs and Insider Perspectives}

The programme Människor och tro is presented as a 'current affairs program about societal issues that concern religion and politics in Sweden and the world'.2

The programme aims to provide in-depth coverage and historical, as well as future-oriented, perspectives and comments. Människor och tro comes under the editorial unit that produces programmes on society (samhällsredaktionen). The editorial staff for Människor och tro consists of two to three people (one programme host, one producer and/or a researcher). About 40 reports in a year are commissioned from freelance journalists. A typical programme is 44 minutes long and consists of a couple of longer reports, including interviews or discussions with invited guests, a brief presentation of the current news on religion,

1 Sveriges Radio, “Mångfald,” 2011, accessed 3 July 2017, http://sverigesradio.se/sida/grup psida. aspx? programid=3113\&grupp=20752\&artikel=5790804

2 Sveriges Radio, “Om Människor och tro,” 2012, accessed 3 July 2017, http://sverigesradio.se/ sida/artikel.aspx?programid=416\&artikel=5285914. 
and reports by international correspondents. The programme is moderated by a programme host and includes possibilities for listeners to interact with the editorial staff, and with each other, through phone-in sessions, email, Facebook, and Twitter.

The policy document (programbeställning) of 2016 for Människor och tro specifies that the programme should examine the impact of religion on individuals and society and identify and debate upon crucial topics that concern religion and values. It also prescribes that the programme should 'take part in people's everyday reality', and that the 'insider perspective should saturate the programme'. Individuals who are 'experts on their own situation' should be given a salient role. During 2015, the programme was commissioned to interact with the audience and to try out a format of broadcasting discussions from places outside of the studio, such as libraries and other public spaces.

This chapter will focus on the representation of Islam and Muslims in Människor och tro in all of the broadcast programmes between January 2014 and April 2015 (62 programmes in total). Starting from the theory of mediatization and religion, we will analyse how the media logic of a current affairs programme on public service radio conditions the programs' engagement with contested issues about religion. We will discuss the relationship between the policy and the aim of the programme, the format of reports, interviews, phone-in sessions, and the Facebook group, and the outcome, in terms of different representations of Islam and Muslims in the programme. We have also interviewed the editorial staff and the producer who worked on the programme during the timespan of our analysis. The interview took place at Sveriges Radio's (SR) headquarters in Stockholm in September 2016.

\subsection{Mediatization of Religion and Conflict}

As discussed in Chapter 4, the mediatization of religion takes several forms. One of these, journalism on religion, refers to how news media and opinion journalism bring religion to the political public sphere. This implies that religious actors, beliefs, and practices will be presented in a way that conforms to the criteria of newsworthiness and critical inquiry.

Simon Cottle $(2006,3)$ argues that a mediatized conflict is a part of the process through which a democratic society can define, challenge, and defend important values in the public sphere. In Cottle's understanding, the role of the media in this process is performative, rather than passive and reflective. To understand the role of the media in tensions and controversies involving religion, we use the framework presented by Hjarvard, Mortensen, and Eskjær (2015; see Chapter 3). 
They suggest that the way in which the media add a dynamic to a conflict can be analysed through three processes: amplification, framing and performative agen$c y$, and co-structuring. In this chapter, we will primarily focus on the dynamics of framing and performative agency, which concern ways in which the media influence the representation of a conflict, its dramaturgy, and how various actors can perform in a situation. Framing describes the process through which media producers 'select some aspects of a perceived reality and make them more salient' in order to 'promote a particular problem definition, causal interpretation, moral evaluation, and/or treatment recommendation' (Entman 1993, 51-52). Frames are produced through the use of certain keywords, phrases, stereotyped images, sources of information, etc., that 'provide thematically reinforcing clusters of facts or judgments' (ibid.). Frames work through referring to, and reinforcing, social conventions, or the 'stock of commonly invoked frames', in a particular context. Framing has implications for the performative agency of the various actors involved. Different frames construct different kinds of positions for acting, and different possibilities for the presenting of arguments in the media. These positions for agency are also structured by the formats and genres of a particular form of media.

In news media, events are framed according to what Kent Asp describes as the institution of 'news media logic'. This institutional logic works as 'a constraint on action since its values and rules reduce uncertainty and provide an overall structure that shapes the behaviour of both the news organizations and individual news journalists' (Asp 2014, 259). News media logic works through a combination of shared professional norms, values, and standards for the production of news. Two important values underpinning the power of news logic (Figenschou, Thorbjørnsrud, and Larsen 2015, 130) is a belief in the significance of news, and the role of journalists as the watchdogs of democracy. These values make journalists into privileged interpreters of 'what goes on in the world and how to talk about it' (ibid.). News media logic builds on, and reproduces, certain generic news frames, such as conflict, economic consequences, and the attribution of responsibility. These frames are often constructed as narratives, which include the roles of both antagonists and protagonists as the actors in a conflict.

Brune (2006, 93-94) identifies four kinds of discursive discrimination in the representation of migrants in the daily press. These are: exclusion from the discourse, often through invisibility; negative representation; objectification by the exclusion of needs and interests; and the normalization of discrimination. These categories reflect how framing can normalize or legitimize problem definitions or treatment recommendations that discriminate against certain groups of people, based on their religious beliefs and practices. In Swedish news media, Muslims 
and presumed Muslims are predominantly represented as the perpetrators or the victims of violence. In very few cases are Muslims portrayed as actors who are willing and able to make a constructive contribution to Swedish society (Axner 2015, 28).

A particular kind of news frame is the human-interest frame. This frame works through making social and political issues interesting through personalization, individual cases, and model stories (Figenschou, Thorbjørnsrud, and Larsen 2015, 131). As Figenschou, Thorbjørnsrud, and Larsen (2015) show in their analysis of asylum conflicts in Norwegian media, these stories tend to focus on the idealized victim, in the form of individuals displaying innocence, morality, and a pleasant personality. The human-interest framing, on the one hand, represents an alternative to the dominant news logic frames of negative representation and objectification. On the other hand, human-interest stories tend to construct one-dimensional characters and hide the complexity of a situation. This may disfavour individuals who fail to display the characteristics of ideal cases, and contribute to a differentiation between "good" and "bad" cases within minority groups. In this way, the human-interest frame can be seen as a form of mediatization of societal conflicts and tensions, in which more complex, structural, or group-based arguments are superseded by a focus on singular events and persons (ibid. 2015, 141).

\subsection{Representing and Framing Islam: Reports}

The first step in our analysis of how the ideals of diversity and nuance are implemented in Människor och tro's representation of Islam, was to analyse the programming time for topics on Islam in relation to those on other religions from January 2014 to April 2015. This was followed by an analysis of how Islam was connected to other societal issues that were addressed in the programmes. Each report in the programmes was categorized by religious tradition, theme, and region. Invited guests and interviewees who were either presented or selfidentified as Muslims were categorized by religious affiliation, profession, and gender. We have also categorized the roles that guests or interviewees were given in the programme as 'expert', 'religious leader', or 'ordinary believer'.

In looking at the representation of different religions, Christianity and Islam are most frequently presented, with an almost equal share of reports during the period. Judaism is covered in 10 percent of the reports. Almost half of the reports focus on Sweden, 19 percent on the Middle Eastern region, and 16 percent on Europe. In terms of themes, the programme lives up to its aim to cover 'the intersection between religion and politics': the most frequent theme, 22 percent of 
the reports, was political issues. Nine percent focussed on terrorism, and an equal amount on theology and culture. Other themes are much less frequent. Looking at co-occurrences between the themes, we see that reports on Christianity also take up issues that are related to politics and theology, culture, and LGBTQ rights. Reports on Islam tend to focus primarily on religious extremism and politics in both the Middle East and Europe, followed by resistance to, and harassment of, Muslims in Sweden and Europe. Turning to invited guest and interviewees, our analysis shows that the Christian denominations are more often represented than the Muslim denominations. Of the persons invited to discussions in the studio during the time period, 32 came from a Christian context and 9 from a Muslim context.

Even if topics such as international conflicts and terror attacks by violent and extremist Islamist groups dominate, several programmes also discussed the situation of Muslims living in Sweden. Frequent topics are the discrimination against Muslim women by members of their own community, as well as by ethnic Swedes; attitudes toward politicians with a Muslim background; discrimination and islamophobia; and radicalization among young Muslims. Three of the programmes on these themes were broadcast from public places outside the studio, where a live audience entered into the debate with reporters and a panel of invited guests from political parties and civil society.

\subsection{Critique and Nuances: Contradicting Demands?}

Människor och tro has a mandate to debate on crucial topics that concern religion and values, but also to counter stereotypes about religion through focusing on people's everyday reality and an 'insider perspective', not least concerning Islam. Our interviews with the producer who is responsible for current affairs programmes, Louise Welander, the programme editor, Tithi Hahn, and the reporter, Jalal Lalouni, revealed some dilemmas that relate to the ways in which these ambitions should be realized. One of these was that religion has generally become a more visible issue in the media during recent decades. When other current affairs programmes and news journalism increasingly focus on religion related news, such as the war and the terror attacks that are carried out by the socalled Islamic State, this increases the demand for Människor och tro to produce a more profound analysis and to find alternative perspectives to the dominating news logic. However, this demand was not matched with the resources to enable it to 'dig deeper' into current news events, or to produce longitudinal, scrutiniz- 
ing research on particular issues. Furthermore, the fact that religion is becoming more of a hot topic in the regular news flow made it more difficult to find participants for interviews and debates in the studio. Several issues, they remarked, were perceived as being controversial, and representatives of some religions felt overly exposed and vulnerable to criticism.

Our analysis reveals the efforts of the editorial team to give voice to a broad range of Muslims in Sweden, such as women, youth, and lay people. Nevertheless, in looking at the profession and gender of these guests, it is clear that male imams and chairpersons of Muslim organizations in Sweden, along with researchers, politicians, and activists in public debates, dominate among the invited guests in the studio (21 of 32). Individuals presented as Muslims were also interviewed, for example in connection with the attacks in Paris, Belgium, and Copenhagen in 2014 and 2015, or about the situation of Muslims in Sweden. Among these interviewees, young women and mothers dominate (19 of 28). A common format in reports is that experiences of such 'ordinary Muslims' are followed by comments and discussion among invited religious leaders and experts in the studio. This format can be seen as a kind of framing, in that such comments privilege particular problem definitions, interpretations, evaluations, or recommendations for the treatment of events and experiences. This framing also affects the performative agency of the actors involved in the programmes. The subject position of an interviewee who shares her or his experiences is changed into a position of object or example in a discussion in which this person is not able to take part on equal terms. However, two programmes break from this format in giving young Muslim women the role of commentators on recent media debates about Muslim men controlling young women's dress and behaviour in suburban communities.

\subsection{Giving Voice to 'Ordinary People’: Phone-In Sessions}

The phone-in sessions are presented as an important strategy through which Människor och tro can achieve the purpose of including insider perspectives on religion, and strengthen dialogue with listeners. Phone-in programmes, as a genre in public service media, invite listeners to participate in a radio programme through sharing their views and opinions on a specific topic (Nordberg 2006; Thornborrow 2001). Our analysis in this section focuses on the organization of the interaction between participants in phone-in sessions, and what implications this has for the performative agency of the different categories of par- 
ticipants. Does the dynamic of the phone-in sessions in Människor och tro differ from the framing that is commonly used in reports about Islam and Muslims in Swedish society? Do they provide for other forms of performative agency for actors who come from minority religious groups to present their perspectives on the presence of religion in the public realm?

Six phone-in sessions took place between January 2014 and April 2015. ${ }^{3}$ Three of these addressed the role of Islam in Swedish society: 'Humor, scorn, hate speech or blasphemy?' (October 2014), 'In what spaces should religion be allowed?' (April 2015), and 'Should religious free schools be allowed?' (October $2015^{4}$ ). In Människor och tro, the programme host moderates the phone-in sessions. Listeners are encouraged to call in either before or during the session, and to send emails to the programme. Staff at the switchboard of SR perform a first sorting of callers, off air. ${ }^{5}$

The call-in sessions are organized following a similar pattern. The host opens the session by referring to a current news event that is related to the chosen theme. One or two calls from listeners, or occasionally emails and Facebook posts, are presented. These comments or questions from listeners are followed by responses from a panel of invited guests, followed by a few more calls, or emails and Facebook posts. In two of the programmes short clips from previous radio programmes are inserted. The first session, on humour and blasphemy, opens with a mix of examples from previous programmes, such as a recording of Pussy Riot's performance 'A Punk Prayer' in Moscow's Cathedral of Christ the Saviour in 2012, a news clip about the Muhammad cartoons controversy in 2005, and a song from the film Life of Brian (1979). The host presents the theme of 'the increasingly multifaceted debate on what is allowed to be said, and what not, about religion'. Listeners who 'may have reflected on, or who have experiences with this topic' are invited to call in. Five callers participated in the programme: one man who self-identified as a Sikh, one women identifying as Christian, and one woman and three men representing a secular standpoint. The callers' opinions on the need for criticism of religion and their experiences of disrespect and violation of religious faith were commented on by two guests: Mona Samadi, a university lecturer in civic law and Islamic law, and Jakob Heidbring, university lecturer in civil law and freedom of speech. Furthermore, Christer Sturmark, the chairperson of the Swedish Humanist Association, and Tuve Skånberg, of the Christian Democratic Party, were invited to call in and dis-

3 The other sessions concerned euthanasia, freedom of consciousness and abortion, the new female Archbishop of the Church of Sweden, and prenatal diagnosis.

4 This session was added to the original period of study due to its relevance.

5 This sorting was not part of the study. 
cuss the theme, due to recent political initiatives that had been taken by these organizations.

The second programme, on the space that religion should be allowed in public, opens with references to whether police officers should be able to wear religious symbols, the allowance of church bells or the muezzin's calls to prayer in public spaces, and end-of-school celebrations in churches. Six callers participated in this session - three men and three women. Two of these had names that signal that they have origins from a country other than Sweden. Arguments ranged from claims about Sweden being a Christian country, the importance of the plurality of religious expressions in the public sphere, and opinions that religion should be expressed in private life or within assigned buildings, and not in other public spaces. Invited guest commenting on the topic and calls were Göran Greider, editor-in-chief of the Social-Democratic leaning newspaper Dala-demokraten, Tara Twana, from the Swedish Humanist Association, and Carl-Henric Jaktlund, the then editor-in-chief of the Christian daily Dagen.

The third session, on allowing religious free schools in Sweden, opened with a provocative question from the host about whether these are to be seen as a 'a unique possibility for integration, or a tax-financed obscenity'. Nine listeners participated through calls and email. Six of these were women, of which the first - a religious education teacher - argued against religious schools, on the basis that they contradict the law relating to the provision of equal education for all pupils. Two men who self-identified as Muslims, also called in. Both of them argued that religious schools are needed, by reference to their own experience of a lack of understanding for the importance of religious plurality in regular Swedish schools. These opinions were commented upon and discussed by Elisabeth Sandberg, the opinion editor of the Christian daily Dagen, Christer Sturmark, of the Swedish Humanist Association, and Claes-Göran Aggebo, from the Swedish National Agency for Education.

\subsection{Dynamics: Moderation, Commentators, and Space}

Previous research on phone-in programmes has shown a high degree of structural regularity in terms of the pre-allocated turns to talk and the distribution of such turns between speakers. This framework both enables and limits the possibilities for participation, in terms of who can speak to whom, when, and for how long (Thornborrow 2001, 119, 121). Our analysis of the interactions in the phonein sessions of Människor och tro shows that the intermediary role of the host is a 
salient feature. The host opens the programme and moderates the exchange between the callers and the invited guests by inviting opinions, asking questions, or interrupting and closing down other participants' speeches.

The regular pattern is that callers comment on the theme only, but invited guests comment on both the theme and the opinions of callers. All the programmes include exchanges between callers. However, these exchanges are brief, and when debates or quarrels arise they are interrupted by the host, for example through call closings such as: 'I am sorry to interrupt, but many more people are waiting to share their opinions,' or 'I just need to say that our programme time is coming to an end, but I hope this debate will continue.' In the sessions on the public place of religion and on religious schools, there are examples of brief direct exchanges between a caller and an invited guest. Nevertheless, it is clear that the host directs these exchanges through follow-up question, or by inviting another speaker to speak. Furthermore, the phone-in sessions in the studio usually end with a round of comments from the invited guests and a summing-up comment from the host, which strengthens this pattern.

Phone-in sessions in Människor och tro differ from those in other phone-in programmes broadcast on Swedish public service radio (Nordberg 2006) in a number of ways. They are brief and are structured as part of a programming time of less than one hour. They also differ in the frequent use of invited guests, who function as commentators on calls. Our analysis shows a pattern in regard to whom the callers and invited guests represent. Guests are representatives of secular humanist associations, Christian politicians, newspaper editors, researchers, and state officials. Callers predominantly represent native Swedish people (men more than women), who often identify as being secular or Christian. Of the 22 people who participated through calls, mail, or Facebook posts in the three sessions that we analysed, only two self-identify as Muslims, and one as a Sikh. Muslims, however, often become represented by other callers, or guests who speak for them, in statements such as: 'I think Muslims are thinking that .... This pattern of representation means that Islam and other minority religions are primarily commented on by representatives of native Swedish people, by secular social institutions, or by Christians.

An additional feature which adds to this dynamic is the access to space. The host and invited guests share the studio space, while callers only share air space for a limited time. Being in the studio or on the telephone also affects the possibility of having a voice in the discussion. Callers' talk is often of poorer sound quality than the talk of the host and the panellists. Comments such as, 'I cannot hear you properly - can you repeat or speak up, please? Are you with us? We lost contact with X' are frequent in the host's interactions with callers. 
David Herbert, Tracey Black, and Ramy Aly $(2013,536)$ point out, in an analysis of discussions about religion in the online forum 'Have Your Say' on the BBC World Service channel, that in spite of constraints to interactivity by the technology and the news media discourses, these debates illustrate the potential to enable complex dialogue among individuals from different contexts about common concerns. Joanna Thornborrow $(2001,134)$, in her study of phone-ins to BBC Radio 1, discusses how the possibility of callers debating with politicians, or other authorities in society, gives the caller the position as a questioner of authorities and dominant discourses.

Our analysis shows that the format of the phone-in sessions in Människor och tro made it difficult for listeners to interact directly, and also to actively react to the framing discourses and production processes which structure the programmes. The host and the invited guests had more speaking time and shared the studio space, and thus had an ability to express their opinions that was greater than that of the listeners who called in. Furthermore, the prominent role of the host in directing follow-up questions and inviting speakers into the conversation, defuses the potentially powerful role of the ordinary person as a questioner of people in institutional positions of power in society. Interviews with the editorial team revealed another aspect that contributes to this pattern. This concerned the tension between combining a plurality of perspectives with a qualified analysis of a topic. While the team strived to find representatives from other groups than 'academics' who tended to be male, middle-aged and of Swedish origin, and who might contribute with everyday experiences of religion, they also argued that guests had to 'fit the format', meaning that even if some people might have had very interesting and relevant experiences they had to be able to articulate these in a short timeframe and during a heated debate. This illustrates the significance of an ability to express arguments in a clear, rational, discursive form in order to participate in the programme.

These aspects contribute to an asymmetrical, rather than a symmetrical, framework of mediated interaction in the programme. The pattern of representatives from majority groups in society who comment on other religious groups, contributes to the framing of minority religions, here, primarily Islam, as the issue or problem at stake in the debates. This framing can contribute to, rather than challenge, a normative understanding in Swedish society that a secular or Christian model for public expressions of religion can be tolerated, but that other religious expressions are an anomaly or problem that must be solved (see Chapter 4). The asymmetry between callers and invited guests also risks reinforcing, rather than reversing, the institutionally inscribed roles of elites and common people in the public discourse. This pattern, as well as the importance of expressing arguments in a particular linguistic form, is probably reinforced by 
the fact that Människor och tro is a public service programme, with an aim to supply an educated, middle-aged segment of the population with high-quality news and in-depth perspectives.

\subsection{Positive Role Models and Identification: A Hijab on Facebook}

A second forum for interactions with the audience is Människor och tro's Facebook page. As pointed out in Chapter 5, PSM are challenged to reach out to younger audiences through digital media. Facebook and Twitter are recent additions to the programme, and the editorial team expressed to us that they still struggled somewhat to integrate these platforms into their work. They found it difficult to get a dialogue going between posters and, due to the lack of time for moderation, they often refrained from promoting more controversial topics from the radio programme, since this might generate antagonistic discussions that they were not equipped to handle.

The most liked and shared posting on the Facebook page during the study concerned a police student named Donna Eljammal. The posting, made on 1 April 2015, followed an earlier interview in the programme (3 April 2014) and included an image of her wearing a hijab and a police uniform:

Donna Eljammal is the first student at the Swedish National Police Academy who wears a headscarf. When the media drew attention to this in a 2011 debate, support and hateful comments online followed. More than three years later, Donna is representing Södertälje Police Office as a receptionist. 'The response here has been surprisingly positive,' she says.

The post received 1,385 'likes' and 61 comments, and it was shared 63 times from the Facebook page. In addition, the post was shared from the archives of text published by sverigesradio.se over 3,000 times in various social media. In comparison, the second most noticed posting, about a teaching student in training who was harassed for wearing a headscarf received 55 'likes', zero comments, and was shared five times.

Only two of the comments expressed criticism of the veiled police student. The majority are positive, short statements that thank and encourage Donna Eljammal. The following is one of the longest and most elaborate:

You are a role model for many women who do not dare to fight for for the profession of their dreams, and you are a strong woman who shows what your heart chose!! Fight on, even if it 
might be hard sometimes. You change society by showing what you chose and how strong you are! Very nice, mashalah.

The names of posters and the frequent adding of 'mashallah'6 at the end of posts indicate that the majority of posters come from, or affiliate themselves with, a Muslim religious tradition. A few of the commenters also engaged in brief discussions about the professions that Muslim women can take up, and how they should dress in public. The editorial team of Människor och tro posted four short statements expressing appreciation for the positive comments, and invitations to listen to the programme. Donna Eljammal herself posts once, saying, 'Thanks everyone for the nice comments. They strengthen and warm my heart. (Feel proud after all these nice comments.)'

The form and content of the Facebook interaction differs in many ways from the patterns discerned in the phone-in sessions. The Facebook interactions have a low degree of moderation and are not commented on by the invited on-air guests. The majority of posters seem to be identifying with Donna Eljammal as young Muslims in Swedish society, and various opinions on Muslim women's dress in public spheres are expressed. The posting is widely 'liked' and shared. However, there is a low degree of interaction between posters.

This example illustrates how Människor och tro seek to realize the policy of Swedish public service radio to counter prejudices and give voice to individuals as 'experts on their own situation'. As pointed out in our analysis of the reports, young Muslim women are often chosen as interviewees, and, on two occasions, as invited guests, to give their perspective on issues raised in the programme. This strategy can, on the one hand, be seen as an alternative to the 'discursive discrimination' of minority groups in news media framing. In the original posting, the 'surprisingly positive response' at the police office to a veiled police woman is contrasted with previous 'hateful comments' in media and online debates. Giving voice to the experiences and opinions of young Muslim women counters invisibility and the stereotypical representation of Muslim women as victims derived of agency. On the other hand, the young Muslim women who are fronted in the programme are, like Donna Eljammal, representatives of Islam in a way that aligns with an established model of religion in Sweden: as an expression of personal belief and as a human right that is also compatible with democratic values, such as gender equality (see Chapter 4). Donna Eljam-

6 The Arabic expression 'mashallah' can be used in a literal religious sense, as a neutral generic saying (detached from its religious roots), or even ironically. Due to the context of commenting on wearing the hijab as a religious symbol, we surmise that it is here being used religiously. 
mal thus becomes a symbol of how a young Muslim woman ideally should take part in, and contribute to, Swedish society. This strategy is also an example of the ambiguous implications of using a human-interest frame in media representations of Islam. By fronting a particular ideal case, this frame aligns with dominant secularist media discourses that tend to dichotomize between religion as personal faith or as an ideology with political claims (Lövheim 2017). While religion is seen as being problematic for a democratic society in both of these discourses, religion as an expression of individual human rights can be accepted, as expressed in the uses of the human-interest frame. This kind of conditioned acceptance of religion as a public expression in Swedish society can, on the one hand, be seen as an example of how the media contribute to the processes of negotiating important values in a democratic society - in this case, how to accommodate religious freedom and certain values of the (secular) majority of society (see Lövheim and Axner 2011; Cottle 2006, 3). On the other hand, it shows how 'alternative' media frames can contribute to upholding a distinction between 'good' religion, as practised by individuals in the private sphere, and 'bad' religion, as public expressions that generate tensions between various opinions and groups.

\subsection{Conclusion: Balancing Contradictory Ideals}

Cultural and religious diversity have become increasingly contested topics in Swedish public debate. As part of the public service media, Människor och tro enables and structures what actors, perspectives, and issues are expressed in this debate, particularly with regard to controversies that relate to Islam. Swedish public service radio has high ambitions to present an alternative to the dominant media discourse that represents Islam as being connected to terrorism and extremism as social problems, and to provide a nuanced insider perspective, rather than repeating the stereotypes of particular groups.

This chapter has shown that Människor och tro provides an equal representation of Christianity and Islam, in terms of programming time, but that Islam is still largely placed in the context of extremism and terrorism. The programme's editorial team strive to counter stereotypes by allowing 'ordinary' Swedish Muslims to comment on such events and to present their experiences and opinions. These are often women, which indicates an effort to give a voice to a minority group. The Facebook posting about the police student, Donna Eljammal, shows an ambition to give a voice to practising Muslims who have found a way to present their religion in public, which has resulted in 'positive' responses and has challenged stereotypes about Islam among the Swedish public. The am- 
bition of the phone-in sessions, to provide a more nuanced public discussion than those seen in the established news formats, is hindered by the structure of the interaction, where the voices of ordinary Muslims are few and, to a large extent, they become framed by the dominant discourses on Islam, which see it as a 'problem' in democratic secular societies. In the words of Sonya Sherefay, a participant in Människor och tro's public hearing on radicalization in the Stockholm suburb Tensta: 'I think you should not just come to us when there is a problem, radio. You should come also when things are good!'

The editorial staff and producers are well aware of the generally negative media image of Islam, and they also know that their way of reporting can reproduce this. However, in response to our finding that most of the reports repeat the image of Islam as being connected to conflicts and terrorism, they responded that it is not their assignment to portray 'everyday Islam'. There has to be a story, they argued, in order for the programme to portray Islam in a good way'. This difficulty of combining critical reporting with a more nuanced image of Islam was enhanced by reactions from listeners who, most prominently, were critical of the programme for focusing too much on Islam and covering up 'dark sides' of religion such as conflicts.

The producers also emphasized the need to differentiate between journalistic programmes on religion, and 'religious programmes', such as worship in religious communities. Människor och tro belongs firmly to the first category, and it is thereby commissioned to report on religion in a critical and factual manner. This tension between an ambition to nuance the news media's framing of Islam and the ideals of good journalism is mirrored in the editorial teams' experiences of communication with what they termed 'religious people'. They had experienced the ways in which 'religious people' felt that they were asked the wrong questions, or were forced into unknown and awkward territory by journalists. One of the reporters explained, 'Religious people do not accept debate as a format, where various opinions are tested against each other. They are reluctant to enter into a format where they cannot control what is being communicated.'

In sum, our analysis of the reports, the interactive formats, and the interviews with the editorial team of Människor och tro illustrate several aspects of the dilemmas that public service media face in balancing traditional ideals and formats, and the ambition to communicate a nuanced image of religion. As a current affairs programme that is traditionally catering for elite segments of the population, the editorial team of Människor och tro follows the traditional journalistic ideals of public service media. The frequent use of invited guests, such as researchers, politicians, other journalists, and leaders from religion and belief organizations, to comment on the experiences and opinions of listeners, follow an attempt to present a critical, in-depth analysis that differs from or- 
dinary news media. However, as these experts often refer to explanatory frames that present public expressions of Islam as a problem in Swedish society, they tend to strengthen a division between 'good' and 'bad' public religion. This tendency is strengthened by journalistic ideals and standards, the 'gut feeling' of what makes a 'good debate', in the phone-in sessions, which tend to privilege the voices of established experts, rather than ordinary listeners. In this way, our analysis of Människor och tro reveals some of the dynamics of the ways in which public service radio enables and structures the visibility of issues, actors, and perspectives that represents Islam and Muslims in contemporary Sweden. These dynamics are shaped by, and contribute to, the public sentiments against religion, in particular, Islam. Swedish citizens may be more tolerant towards expressions of Islam in the public sphere than their Scandinavian neighbours, but, as our analysis shows, the possibility for Muslim citizens to make their voices heard is still structured by the traditions, rules, and values that are formed by the majority of the participants in this public discourse.

\section{Bibliography}

Asp, Kent. 2014. "News Media Logic in a New Institutional Perspective." Journalism Studies 15 (3): $256-270$.

Axner, Marta. 2015. "Representationer, stereotyper och nyhetsvärdering.

Rapport från medieanalys om representationer av muslimer i svenska nyheter." [Representations, stereotypes and news values. A media analysis of representation of Muslims in Swedish news]. Stockholm: DiskrimineringsOmbudsmannen (DO). Accessed 30 June 2017. http://www.do.se/om-diskriminering/publikationer/representationer-stereo typer-och-nyhetsvardering/.

Brune, Ylva. 2006. "Den dagliga dosen. Diskriminering i Nyheterna och Bladet.” [The daily dose. Discrimination in the news and the paper]. In Mediernas vi och dom. Mediernas betydelse för den strukturella diskrimineringen, edited by Leonor Camauër and Stig Arne Nohrstedt, 89-122. SOU 2006: 21.

Cottle, Simon. 2006. Mediatized Conflict: Developments in Media and Conflict Studies. Maidenhead: Open University Press.

Entman, Robert M. 1993. "Framing: Toward Clarification of a Fractured Paradigm.” Journal of Communication 43 (4): 51-58.

Figenschou, Tine Ustad, Kjersti Thorbjørnsrud, and Anna M. Grøndahl Larsen. 2015. "Mediatized Asylum Conflicts: Human-Interest Framing and Common-Sense Public Morality." In The Dynamics of Mediatized Conflicts, edited by Mikkel Fugl Eskjær, Stig Hjarvard, and Mette Mortensen, 129-145. New York: Peter Lang.

Herbert, David, Tracey Black, and Ramy Aly. 2013. "Arguing about Religion: BBC World Service Internet Forums as Sites of Postcolonial Encounter." Journal of Postcolonial Writing 49 (5): $519-538$. 
Hjarvard, Stig, Mette Mortensen, and Mikkel Fugl Esjkær. 2015. "Introduction: Three Dynamics of Mediatized Conflicts." In The Dynamics of Mediatized Conflicts, edited by Mikkel Fugl Eskjær, Stig Hjarvard and Mette Mortensen, 1-27. New York: Peter Lang. Horsti, Karina, and Gunilla Hultén. 2011. "Directing Diversity. Managing Cultural Diversity Media Policies in Finnish and Swedish Public Service Broadcasting." International Journal of Cultural Studies 14 (2): 209-227.

Ipsos. 2016. "Stort förtroende för Sveriges Television och Sveriges Radio." [Strong trust in Swedish Television and Swedish Radio]. Accessed 3 July 2017 http://ipsos.se/160401DN-Ipsos-Mediefortroende

Kantar Sifo. 2017. Accessed 10 January 2018 https://www.kantarsifo.se/rapporter-under sokningar/radioundersokningar/radioresultat-nationell-radio-ppm

Lövheim, Mia. 2017. "Religion, Mediatization and 'Complementary Learning Processes' in Swedish Editorials." Journal of Religion in Europe 10 (4): 366-383.

Lövheim, Mia, and Alf Linderman. 2015. "Religion, Media, and Modernity: Editorials and Religion in Swedish Daily Press." In Is God Back? Reconsidering the New Visibility of Religion, edited by Titus Hjelm, 32-45. London: Bloomsbury.

Lövheim, Mia, and Marta Axner. 2011. "Halal-TV: Negotiating the Place of Religion in Swedish Public Discourse.” Nordic Journal of Religion and Society 24 (1): 57-74.

Nordberg, Karin. 2006. Folkhemmets nya röster. Ring P1 - en alternativ offentlighet? [New voices of the people. Call P1 - an alternative public?]. Stockholm: Stiftelsen Institutet för mediestudier.

Nordicom. 2016. The Media Barometer. Accessed 10 January 2018 http://nordicom.gu.se/en/ statistics-facts/media-barometer

Thornborrow, Joanna. 2001. "Questions, Control and the Organization of Talk in Calls to a Radio Phone-In.” Discourse Studies 3 (1): 119-143. 